\title{
Study of different biochemical markers: bikunin, follistatin and activin significance in different types of ovarian cancer
}

\author{
Gihan M Sharara ${ }^{(1)}$, Samer M Zahran ${ }^{(2)}$, Mohamed A El-Samra ${ }^{(3)}$. \\ ${ }^{(1)}$ Medical Biochemistry, Faculty of Medicine, Alexandria University, \\ ${ }^{(2)}$ Medical Biochemistry, Faculty of Medicine, Tanta University, \\ ${ }^{(2)}$ Obstetrics and Gynecology, Faculty of Medicine, Alexandria University
}

\begin{abstract}
OVARIAN CANCER HAS the second highest incidence in gynecological cancers and is the fifth leading cause of cancer death among women in the world. Characterizing the pathways that regulate the growth of ovarian cells is necessary for understanding the events that lead to development of ovarian cancer. The aim of the present study was to evaluate the potential clinical implication of circulating Activin A, follistatin, bikunin, ovarian tissue urokinase Plasminogen Activator (uPA) and Smad-2 (fusion between Drosophila mothers against dpp (Mad) and C. elegans Sma)expression for diagnosis and progression of ovarian cancer. Subjects: The study was carried out on 75 women divided as follows: 15 women with serous ovarian carcinoma, 15 women with mucinous ovarian carcinoma, 15 women with serous ovarian cystadenoma, 15 fertile healthy women, 15 postmenopausal healthy women.

Methods: Serum levels of Activin A and Follistatin, and Plasma levels of Bikunin were estimated using ELISA. Urokinase plasminogen activator (uPA) was extracted from ovarian cancerous tissue and its levels estimated by ELISA. Detection of Smad2 mRNA in ovarian tissue was performed by Reverse Transcription Polymerase Chain Reaction analysis (RT-PCR). Results: The levels of serum Activin $A$ and Follistatin were found to be significantly higher in serous and mucinous ovarian carcinoma than in ovarian cystadenoma and controls (pre- and postmenopausal). Plasma levels of Bikunin were estimated to be significantly lower in patients with serous ovarian carcinoma and mucinous ovarian carcinoma than in controls and than patients with ovarian cystadenoma. In the present study, levels of uPA in ovarian tissue were significantly higher in serous ovarian carcinoma than in ovarian cystadenoma and controls. Levels of UPA were significantly higher in mucinous ovarian carcinoma than all other groups. Levels of uPA were found to be increased with progression of the stage of ovarian tumor. Correlation studies showed direct positive significant correlations between Activin A and Follistatin, Activin A and $u P A$, Follistatin and $u P A$. Also, Bikunin was found to be inversely correlated to Activin A, Follistatin and UPA. Smad-2 expression was detected in $75 \%$ of cases of serous ovarian cystadenocarcinoma, in $90 \%$ of mucinous ovarian carcinoma.

Conclusions: In summary, activin A induces the proliferation of both serous and mucinous ovarian carcinoma. Therefore, activin A may be regarded as both a
\end{abstract}


potential growth factor and a tumor marker. The significantly elevated levels of serum follistatin (Activin - binding protein) in ovarian carcinoma indicated that activin is free and this modulated its signal transduction as illustrated by the expression of Smad-2 in $90 \%$ of mucinous ovarian carcinoma and in $75 \%$ of serous cystadenocarcinoma. The present study shows that the activin/Smad signaling pathway is functional in ovarian cancer cells which most probably promotes tumor growth. It is proposed that Smad-2 increased the levels of uPA which is a proteolytic enzyme that enhances tumor growth, progression, invasion and metastases. Plasma bikunin concentration might be a strong and independent favorable prognostic marker for ovarian cancer. It may be concluded that bikunin might attenuate Activin A-elicited signaling cascades in ovarian cancer this probably suppresses uPA expression. Treatment with bikunin may be beneficial to delay the appearance of metastatic disease and/or combined with cytotoxic agents to improve treatment efficacy in advanced ovarian cancers.

\section{INTRODUCTION}

OVARIAN cancer is considered the second highest incidence in gynecological cancers, ranks first in gynecologic cancer-related mortality, and is the fifth leading cause of cancer death among women world-wide ${ }^{(1)}$. If ovarian cancer is detected early, more than $93 \%$ of patients survive $\geq 5$ years; however, more than $75 \%$ of cases are diagnosed at advanced stages with a poor prognosis for survival (American Cancer Society) ${ }^{(\mathbf{1})}$. Most ovarian cancers are believed to arise from the ovarian surface epithelium (OSE), a modified peritoneal mesothelium derived embryologically from the coelomic epithelium. Characterizing the pathways that regulate the growth of OSE cells is a necessary first step toward understanding the events that lead to uncontrolled cellular proliferation and the development of ovarian cancer ${ }^{(1)}$.

There appears to be a decreased risk of ovarian neoplasia with circumstances that decrease ovulatory frequency such as increased parity, breast feeding, and oral contraceptive use, whereas some studies seem to show an increased risk with the use of infertility drugs, although this finding remains controversial. These epidemiological findings suggest that suppression of folliculogenesis may be an important factor in decreasing the risk of epithelial ovarian cancer. ${ }^{(2)}$

Human OSE cells express many of the receptors for hormones and growth factors produced by the ovarian surface epithelial, follicular, and stromal cells, leading to the suggestion that epithelial cell activity may be modified by autocrine and paracrine signals ${ }^{(1)}$.

Activin $\mathrm{A}$ is a dimeric protein member of the transforming growth factor beta (TGFß) superfamily ${ }^{(3,4)}$ composed of two $\beta$-subunits, $B A-\beta A$ (activin A), BB-BB (activin B), or $B A-$ $\beta \mathrm{B}(\text { activin } \mathrm{AB})^{(5)}$. It is synthesized by a variety of organs including normal endometrium. Activin A acts as an important regulator of cell growth and differentiation ${ }^{(4)}$. Activin was originally identified as an inducer for follicle-stimulating hormone (FSH) from the pituitary, and it has a central 
role in the regulation of the reproductive $\operatorname{axis}^{(6)}$. Follistatin is a soluble secreted glycoprotein that suppresses the release of FSH by binding to Activin and inhibiting its interaction with Activin receptors ${ }^{(7)}$.

However, as Activin is produced locally in the ovary, it has been hypothesized that it may act via an autocrine/paracrine mechanism to regulate ovarian function ${ }^{(5)}$. Activin mediates its cellular effects through heterodimeric complexes of type I and II Activin serine/threonine kinase receptors. The importance of the Activin in regulating cell proliferation and possibly ovarian tumor development has been suggested by Fukuda et al; in $1998^{(8)}$. To transmit the signal intracellularly, type I receptors activate a member of the SMAD family, which then translocates to the nucleus. Based on structural and functional characteristics, the Smad family is divided into three distinct classes: receptor-regulated Smads (R-Smads), common-mediator Smads (CoSmads), and inhibitory Smads (ISmads). R-Smads include Smad2 and 3 , which are specifically recognized by activin and TGF $\beta$ type I receptors, and Smad1, 5, and 8, which are used by bone morphogenetic proteins (BMP) receptors ${ }^{(9)}$.

Receptor-regulated Smads, become phosphorylated by activated type I receptors and form heteromeric complexes with a common-partner Smad4, which translocates into the nucleus to control gene transcription. In addition to these signal transducing Smads, inhibitory Smads have been identified that inhibit the activation of receptor-regulated Smads. ${ }^{(\mathbf{1 0 , 1 1})}$ Once in the nucleus, both R-Smad and CoSmad may participate in DNA binding and recruitment of transcriptional cofactors $^{(11)}$. Stimulation by activin results in the formation of complexes that contain forkhead activin signal transducer-1 (FAST-1), Smad2, and Smad4. Smad2 associates directly with FAST-1, whereas Smad4 contributes additional DNA binding specificity and transcriptional activation functions to the complex ${ }^{(12)}$.

Moreover, once recruited to specific elements, both $\mathrm{Smad} 2 / 3$ and Smad4 can activate transcription by recruiting additional co-activators that have histone acetyl transferase activity such as $\mathrm{CBP} / \mathrm{p} 300^{(\mathbf{1 3})}$. Alternatively, they can recruit corepressors such as TGIF or Ski family members, which in turn bind histone deacetylases ${ }^{(14)}$. Thus, Smads can positively or negatively regulate transcription of specific genes in response to activin/TGFß signaling ${ }^{(\mathbf{9}) \text {. }}$ Thus, Smads play a critical role in transmitting the intracellular signal of TGFß family ligands, including Activin A. Therefore, Smad-2 might explain the role of activin $\mathrm{A}$ in ovarian cancer $^{(9)}$.

Considering the critical role Smads play in transmitting the intracellular signal of TGFß family ligands, it is not surprising that cells regulate the availability of Smad at multiple levels. For example, Smad2 access to the type I receptor is modulated by a protein named Smad anchor for receptor activation (SARA), which binds unphosphorylated Smad2, thereby masking its nuclear localization signal and maintaining a cytoplasmic distribution. Upon receptor activation, 
SARA interacts with the type I receptor to facilitate Smad2 phosphorylation and activation. As a result, Smad2 dissociates from SARA and complexes with Smad4, after which the complex translocates to the nucleus ${ }^{(9)}$.

Follistatin (FS) was first identified as a follicle-stimulating hormone inhibiting substance (i.e. structurally distinct from inhibin) present in ovarian follicular fluid ${ }^{(15)}$. It has since been shown to be a multifunctional regulatory protein exerting a majority of its effects via neutralization of activin. FS is a monomeric binding protein that regulates activin activity by forming an inactive complex. FS plays a role as a tissue regulator in the gonad, pituitary gland, pregnancy membranes, vasculature, and liver ${ }^{(16)}$. It is also essential for normal development.

FS is a single-chain polypeptide with a structure unlike activin or inhibin. Alternative splicing events, proteolytic cleavage and variable glycosylation lead to a vast array of possible FS isoforms found within various biological fluids. ${ }^{(16)} \mathrm{FS}$ in the circulation is most likely full-length FS 315 whereas FS in follicular fluid is predominately processed. Nearly all FS in circulation is bound to activin, and FS most likely acts as an autocrine/paracrine rather than endocrine factor in a number of tissues to regulate activin and other TGFß superfamily members. ${ }^{(9)}$

FS is commonly found colocalized within a tissue with activin subunits or activin receptors. Activin/FS complexes may also bind extracellular matrix components thus forming reservoirs of activin/FS. Within the circulation, $70-90 \%$ of FS exists in the bound state ${ }^{(17)}$. FS binds to the common $\alpha \mathrm{A}$ and $\beta \mathrm{B}$ subunits of activin and inhibin. Therefore, activin has two binding sites for FS (i.e. one activin dimer and two FS monomers make up the activin-FS complex), whereas inhibin has only one (17). Activin $\mathrm{A}, \mathrm{AB}$, or $\mathrm{B}$ each binds $\mathrm{FS}$ with similar affinity. Since inhibin contains only one $\beta$-subunit, it binds FS with a lower affinity ${ }^{(18)}$.

FS does not bind activin exclusively. It can bind other members of the TGF- $\beta$ superfamily, including BMP-4 and BMP- $7^{(19)}$. It is also capable of binding the serum protein a2-macroglobulin, itself another binding protein for activin ${ }^{(19)}$. FS has a strong affinity for heparan sulfate and can associate with heparan sulfate proteoglycans on cell surfaces ${ }^{(20)}$. Following binding to cell surface proteoglycans, activin/FS complexes can be rapidly endocytosed by lysosomal enzymes ${ }^{(21)}$.

The high affinity of activin-FS interaction approaches irreversibility due to its slow dissociation rate, rendering the bound activin unavailable for binding to its own (activin-RII/RIIB) receptor. The bound complex consists of two FS molecules for each activin $\beta / \beta$ homodimer ${ }^{(9)}$.

The biological effects of activin A are counteracted by follistatin (22), which is a high affinity extracellular binding protein for activin $\mathrm{A} .{ }^{(23)}$ Thus, follistatin modulates activin signaling even before it binds to its receptor, thus provides the first line of regulatory action of activin- $\mathrm{A}^{(9)}$ .However, clinical data linking activin 
A and follistatin are lacking and it is unknown whether their serum concentrations have any correlation with carcinoma cell differentiation. ${ }^{(24)}$.

In addition, circulating activin appears to be bound to FS virtually irreversibly, suggesting that for endocrine activin to have distant actions it would have to be released from FS by some proteolytic mechanism. Such a mechanism has been identified for the related BMPs, in which bioactive BMP is released by cleavage of its binding protein, chordin, by the metalloproteinase, tolloid. Until this type of mechanism is identified for activin, most attention has been, and will likely continue to be, focused on the local autocrine/paracrine actions of activin. $^{(9)}$

Bikunin is a multifunctional glycoprotein $^{(25)}$, chondroitin sulfatecontaining plasma protein synthesized in the liver. In vitro, it has been shown to inhibit proteases. It is a Kunitz-type protease inhibitor and has additional activities, but its biological function is still unclear. ${ }^{\text {(26) }}$ The processes of ovarian cancer dissemination are characterized by altered local proteolysis, cellular proliferation, cell attachment, and invasion. Thus Bikunin could be involved in the pathogenesis of ovarian cancer progression and peritoneal dissemination. ${ }^{(27)}$

Invasion and metastasis of solid tumors require proteolytic enzymes that degrade the extracellular matrix and basement membranes. Among the proteases involved are the plasminogen activators, of which urokinase-type plasminogen activator (uPA) has been suggested to play a central role. Binding of uPA to the uPA receptor (CD87) activates the protease and catalyzes the conversion of plasminogen to plasmin, which subsequently activates type IV collagenase, or directly degrades extracellular matrix proteins such as fibrin, lamin, laminins, and proteoglycans. uPA has been associated with disease outcome as statistically independent prognostic markers in breast, lung, colon, kidney, and gastrointestinal cancers. ${ }^{(28)}$ Thus uPA could have a role in the pathogenesis of ovarian cancer progression.

The aim of the present study is to evaluate the potential clinical implication of circulating Activin A, follistatin, bikunin, endometrial tissue uPA and Smad-2 expression for diagnosis and progression of ovarian cancer.

\section{SUBJECTS \& METHODS}

The study was carried out on 75 women admitted to Alexandria University Gynecology Hospital divided into the following groups: group 1: 15 women with serous ovarian carcinoma, group 2: 15 women with mucinous ovarian carcinoma, group 3: 15 women with serous ovarian cystadenoma, group 4: 15 fertile premenopausal healthy women, and group 5: 15 postmenopausal healthy women. Patient and disease characteristics of ovarian cancers are shown in table (1). 
Table (1) Patient and Disease Characteristics of Ovarian Cancers

\begin{tabular}{|l|c|c|}
\hline & $\begin{array}{c}\text { Group 1: } \\
\text { Serous ovarian } \\
\text { carcinoma }\end{array}$ & $\begin{array}{c}\text { Group 2: } \\
\text { Mucinous ovarian } \\
\text { carcinoma }\end{array}$ \\
\hline AGE: & $\begin{array}{c}\text { Range } \\
\text { Median }\end{array}$ & $\begin{array}{c}45-77 \text { years } \\
60 \text { years }\end{array}$ \\
\hline $\begin{array}{l}\text { Number of patients without } \\
\text { metastasis years }\end{array}$ & 7 & 8 \\
\hline $\begin{array}{l}\text { Number of patients with } \\
\text { metastasis }\end{array}$ & 8 & 7 \\
\hline
\end{tabular}

All the included cases will be subjected to the following:

I. Thorough history taking and clinical examination.

II. Laboratory investigations included

1. Serum levels of activin A were estimated using ELISA ${ }^{(29)}$

2. Serum levels of follistatin were estimated using the Quantikine Follistatin Immunoassay ELISA (30)

3. Plasma levels of bikunin were estimated using ELISA (On EDTA). ${ }^{(31)}$

4. Tissue Collection and Extraction for $\mathbf{u P A}^{(\mathbf{3 2})}$. Tissue samples were collected during surgery and stored in liquid nitrogen for further analysis. 500 mg wet weight of ovarian tissue were pulverized in the frozen state by a micro-dismembrator (Braun-Melsungen, Melsungen, Germany) and resuspended in a buffer containing $0.02 \mathrm{M}$ Tris$\mathrm{HCl}(\mathrm{pH} 8.5), 0.125 \mathrm{M} \mathrm{NaCl}$, and $1 \%$ Triton X-100 under gentle rotation at $4^{\circ} \mathrm{C}$. The lysate was centrifuged for $45 \mathrm{~min}$ at $4^{\circ} \mathrm{C}$, and an aliquot of the supernatant was assayed for protein concentration using the BCA Protein Assay reagent kit (Pierce, Rockford, IL) $)^{(32)}$.

uPA

uPA antigen concentrations were determined by ELISA kits (American Diagnostica, Greenwich, CT). Protein content of the tissue extracts was determined. uPA antigen values were expressed as $\mathrm{ng} / \mathrm{mg}$ $\operatorname{protein}^{(32)}$.

5. Detection of Smad2 mRNA by RT-PCR analysis ${ }^{(1,33)}$

Total RNA were obtained from fresh-frozen ovarian tissues during surgery from all patients (33). Total cytoplasmic RNA for RT-PCR was isolated from ovarian cancer tissue using the single-step guanidinium isothiocyanate method ${ }^{(1)}$.

Complementary DNA (cDNA) was synthesized from $10 \mu \mathrm{g}$ of total cellular RNA by reverse transcription with Moloney murine leukemia virus reverse transcriptase (Life Technologies, Inc.) using random hexamers as primers ${ }^{(33)}$.

RT-PCR was used to detect expression of smad2 target gene (30 
cycles: $35 \mathrm{sec}$ at $94 \mathrm{C}, 35 \mathrm{sec}$ at 59.5 C, $35 \mathrm{sec}$ at $72 \mathrm{C})^{(\mathbf{1})}$. The Smad2 sense and antisense primers were used. The PCR mixture contained $50 \mathrm{mM}$ Tris (pH 9.0), $50 \mathrm{mM} \mathrm{KCl}, 1.5 \mathrm{mM}$ $\mathrm{MgCl}_{2}, 0.01 \%$ gelatin, $100 \mathrm{ng}$ of each primer, and 1 unit Taq polymerase (Life Technologies, Inc.). After an initial denaturation at $94^{\circ} \mathrm{C}$ for $5 \mathrm{~min}$, amplification was carried out for 30 cycles at $94^{\circ} \mathrm{C}$ for $30 \mathrm{~s}, 55^{\circ} \mathrm{C}$ for 1 $\mathrm{min}$, and $72^{\circ} \mathrm{C}$ for $1 \mathrm{~min}$, followed by a final elongation step at $94^{\circ} \mathrm{C}$ for 2 $\min , 55^{\circ} \mathrm{C}$ for $2 \mathrm{~min}$, and $72^{\circ} \mathrm{C}$ for 10 min. The PCR products were electrophoresed on a $2 \%$ agarose gel and stained with ethidium bromide. ${ }^{(1)}$

STATISTICS: The values of the measured parameters were expressed as mean \pm SD. The difference between groups was determined using ANOVA test (F-test). Pearson's correlation coefficient was performed for detection of the possible relation between the laboratory and biochemical variables. $\mathrm{P}<0.05$ values were considered significant. All statistical analyses were processed using SPSS for windows, version 8.0.

\section{RESULTS}

Table (2): Serum Levels of Activin-A in the Studied Groups

\begin{tabular}{|c|c|c|c|c|c|}
\hline $\begin{array}{c}\text { Activin A } \\
(\mathbf{p g} / \mathbf{m l})\end{array}$ & $\begin{array}{c}\text { Group 1 } \\
\text { Serous ovarian } \\
\text { carcinoma }\end{array}$ & $\begin{array}{c}\text { Group 2 Mucinous } \\
\text { ovarian carcinoma }\end{array}$ & $\begin{array}{c}\text { Group 3 } \\
\text { Serous } \\
\text { cystadenoma }\end{array}$ & $\begin{array}{c}\text { Group 4 } \\
\text { Control } \\
\text { premenopausal }\end{array}$ & $\begin{array}{c}\text { Group 5 } \\
\text { Control } \\
\text { postmenopausal }\end{array}$ \\
\hline Number & 15 & 15 & 15 & 15 & 15 \\
\hline Mean & 1417.7 & 1604.33 & 1244.4 & 621.6 & 637.6 \\
\hline SD & 62.56 & 63.49 & 69.07 & 50.69 & 57.80 \\
\hline Range & $1296-1480$ & $1530-1690$ & $1160-1339$ & $558-685$ & $580-730$ \\
\hline F & \multicolumn{5}{|c|}{} \\
\hline P & \multicolumn{5}{|c|}{$0.0001^{*}$} \\
\hline
\end{tabular}

* Significant at $\mathrm{p}<0.05$ between group 1 and both group 3 and controls; between group 2 and all other groups.

Table (3): Serum Levels of Follistatin in the Studied Groups

\begin{tabular}{|c|c|c|c|c|c|}
\hline $\begin{array}{c}\text { Follistatin } \\
(\mathbf{p g} / \mathbf{m l})\end{array}$ & $\begin{array}{c}\text { Group 1 } \\
\text { Serous ovarian } \\
\text { carcinoma }\end{array}$ & $\begin{array}{c}\text { Mucinous ovarian } \\
\text { carcinoma }\end{array}$ & $\begin{array}{c}\text { Group 3 Serous } \\
\text { cystadenoma }\end{array}$ & $\begin{array}{c}\text { Group 4 Control } \\
\text { premenopausal }\end{array}$ & $\begin{array}{c}\text { Group 5 Control } \\
\text { postmenopausal }\end{array}$ \\
\hline Number & 15 & 15 & 15 & 15 & 15 \\
\hline Mean & 835.7 & 1276.67 & 642.2 & 392.0 & 396.0 \\
\hline SD & 39.88 & 266.79 & 65.42 & 70.49 & 54.13 \\
\hline Range & $780-890$ & $980-1600$ & $550-780$ & $320-500$ & $320-470$ \\
\hline F & \multicolumn{5}{|c|}{$0.0001 *$} \\
\hline P & * Significant at p<0.05 between group 1 and both group 3 and controls; between group 2 and all \\
other groups.
\end{tabular}


Table (4): Plasma Levels of Bikunin In The Studied Groups

\begin{tabular}{|c|c|c|c|c|c|}
\hline $\begin{array}{c}\text { Bikunin } \\
(\boldsymbol{\mu g} / \mathbf{m l})\end{array}$ & $\begin{array}{c}\text { Group 1 } \\
\text { Serous ovarian } \\
\text { carcinoma }\end{array}$ & $\begin{array}{c}\text { Group 2 } \\
\text { Mucinous ovarian } \\
\text { carcinoma }\end{array}$ & $\begin{array}{c}\text { Group 3 Serous } \\
\text { cystadenoma }\end{array}$ & $\begin{array}{c}\text { Group 4 } \\
\text { Control } \\
\text { premenopausal }\end{array}$ & $\begin{array}{c}\text { Group 5 } \\
\text { Control } \\
\text { postmenopausal }\end{array}$ \\
\hline Number & 10 & 10 & 10 & 10 & 10 \\
\hline Mean & 11.55 & 11.08 & 16.16 & 18.94 & 0.84 \\
\hline SD & 0.31 & 0.45 & 0.82 & $18.1-20.1$ & $18.2-19.7$ \\
\hline Range & $11.1-12.1$ & $10.5-11.6$ & $15.1-17.1$ & \\
\hline F & \multicolumn{5}{|c|}{} \\
\hline P & \multicolumn{5}{|c|}{$0.0001^{*}$} \\
\hline
\end{tabular}

* significant at $\mathrm{p}<0.05$ : significantly lower in group 1 and group 2 than in controls and than group 3 , and also plasma bikunin levels were found to be significantly lower in group 3 than in controls.

Table (5): Levels of uPA in Endometrial Tissue in the Studied Groups

\begin{tabular}{|c|c|c|c|c|c|}
\hline $\begin{array}{c}\text { uPA } \\
\text { (ng/mg } \\
\text { protein) }\end{array}$ & $\begin{array}{c}\text { Group 1 } \\
\text { Serous ovarian } \\
\text { carcinoma }\end{array}$ & $\begin{array}{c}\text { Group 2 Mucinous } \\
\text { ovarian carcinoma }\end{array}$ & $\begin{array}{c}\text { Group 3 Serous } \\
\text { cystadenoma }\end{array}$ & $\begin{array}{c}\text { Group 4 } \\
\text { Control } \\
\text { premenopausal }\end{array}$ & $\begin{array}{c}\text { Group 5 } \\
\text { Control } \\
\text { postmenopausal }\end{array}$ \\
\hline Number & 10 & 10 & 10 & 10 & 10 \\
\hline Mean & 3.82 & 5.45 & 2.45 & 0.614 & 0.25 \\
\hline SD & 0.44 & 0.30 & 0.32 & 0.25 & $0.5-1.7$ \\
\hline Range & $3.2-4.4$ & $5.0-5.9$ & $2.0-2.9$ & $0.24-1.00$ & 0.36 \\
\hline F & \multicolumn{5}{|c|}{$0.001 *$} \\
\hline P & * Significant at $\mathrm{p}<0.05:$ significantly higher in group 1 and group 2 than in controls and than group 3, and
\end{tabular}
significantly higher in group 3 than in controls.

Table (6): The Correlation Study between the Studied Groups

\begin{tabular}{|c|c|c|c|c|}
\hline & Activin A & Follistatin & Bikunin & uPA \\
\hline \multirow{2}{*}{ Activin A } & $\mathrm{r}=1.0$ & $\mathrm{r}=0.87$ & $\mathrm{r}=-0.92$ & $\mathrm{r}=0.96$ \\
& $\mathrm{p}=--$ & $\mathrm{p}=0.001$ & $\mathrm{p}=0.0001$ & $\mathrm{p}=0.001$ \\
\hline \multirow{2}{*}{ Follistatin } & $\mathrm{r}=0.87$ & $\mathrm{r}=1.0$ & $\mathrm{r}=-0.86$ & $\mathrm{r}=0.93$ \\
& $\mathrm{p}=0.001$ & $\mathrm{p}=--$ & $\mathrm{p}=0.001$ & $\mathrm{p}=0.001$ \\
\hline \multirow{2}{*}{ Bikunin } & $\mathrm{r}=-0.92$ & $\mathrm{r}=-0.86$ & $\mathrm{r}=1.0$ & $\mathrm{r}=-0.95$ \\
& $\mathrm{p}=0.0001$ & $\mathrm{p}=0.001$ & $\mathrm{p}=--$ & $\mathrm{p}=0.001$ \\
\hline \multirow{2}{*}{ uPA } & $\mathrm{r}=0.96$ & $\mathrm{r}=0.93$ & $\mathrm{r}=-0.95$ & $\mathrm{r}=1.0$ \\
& $\mathrm{p}=0.001$ & $\mathrm{p}=0.001$ & $\mathrm{p}=0.001$ & $\mathrm{p}=--$ \\
\hline
\end{tabular}

* Significant at $\mathrm{p}<0.05$ 
The levels of Activin A were found to be significantly higher in serous ovarian carcinoma than in ovarian cystadenoma and controls. Levels of Activin A were significantly higher in mucinous ovarian carcinoma than all other groups, including serous ovarian carcinoma. Also levels of Activin were significantly higher in serous ovarian cystadenoma than controls. $(\mathrm{F}=299.73, \mathrm{p}=0.0001)$ (Table 2).

In the present study, levels of serum Follistatin were found to be significantly higher in serous ovarian carcinoma than in ovarian cystadenoma and controls (pre- and postmenopausal). Levels of Follistatin were significantly higher in mucinous ovarian carcinoma than all other groups, including serous ovarian carcinoma. Also levels of Follistatin were significantly higher in serous ovarian cystadenoma than controls. $(\mathrm{F}=54.75, \mathrm{p}=0.0001)($ Table 3$)$

Plasma levels of Bikunin were found to be significantly lower in patients with serous ovarian carcinoma (Group 1) and mucinous ovarian carcinoma (group 2) than in controls (group 4 and 5) and than patients with ovarian cystadenoma, and also serum Bikunin levels were found to be significantly lower in ovarian cystadenoma than in controls. $(\mathrm{F}=231.22, \mathrm{p}=0.0001)$ (Table 4).

In the present study, levels of uPA in ovarian tissue were significantly higher in serous and mucinous ovarian carcinoma than in ovarian cystadenoma and controls (pre- and postmenopausal). Also levels of uPA were significantly higher in ovarian carcinoma with metastases than those without metastases. Levels of uPA were found to be increased with progression of the stage of ovarian tumor. $(\mathrm{F}=$ $338.86, \mathrm{p}=0.001)($ Table 5).

On performing correlation studies between the studied parameters, direct positive correlation was found between Activin and Follistatin (correlation co-efficient $(\mathrm{r}=0.87, \mathrm{p}<$ 0.001). Also a significant negative correlation was detected between Activin and Bikunin (correlation coefficient $(\mathrm{r}=-0.92, \mathrm{p}<0.001)$, and between Follistatin and Bikunin (correlation co-efficient ( $\mathrm{r}=-0.86, \mathrm{p}$ $<0.001$ ). Finally, uPA was found to be significantly positively correlated with activin A, Follistatin $(r=0.96$, 0.93 , respectively at $\mathrm{p}<0.01)$ and inversely correlated with bikunin $(\mathrm{r}=$ - 0.95 at $\mathrm{p}<0.01$ ) (Table 6).

Results of Smad-2 mRNA by RTPCR (Figure 1)

Total RNA obtained from ovarian tumors (serous, mucinous ovarian carcinoma and cystadenoma) was reverse transcribed as described in "Methods." The resulting cDNA was PCR-amplified using primers specific for Smad2. Positive control (+), plasmids encoding the cDNA for Smad2; negative control (-), water. Figure (1) shows the result of RTPCR of 10 ovarian tumors which highly expressed Smad-2. Smad-2 expression was found in $75 \%$ of cases of serous ovarian cystadenocarcinoma (group 1), in $90 \%$ of mucinous ovarian carcinoma (group 2), in 30\% of cystadenoma (group 3) and only $10 \%$ of the controls expressed Smad-2 (group 4 and 5). 


\section{RT- PCR Analysís}

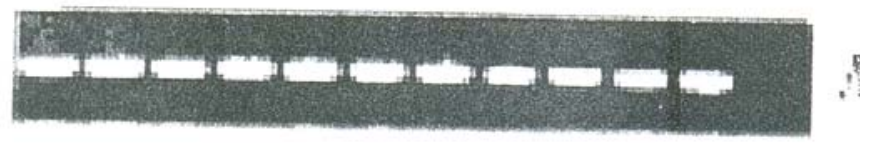

$$
1254517910+.
$$

Figure 1. The figure is a representative RT-PCR data from ovarian cancer cells indicating expression of Smad2. Expression of Smad2 mRNA in ovarian cancer cells. Total RNA obtained from ovarian tumors was reverse transcribed as described in "Methods." The resulting cDNA was PCR-amplified using primers specific Smad2. Positive control (+), plasmids encoding the cDNA for Smad2; negative control (-).

\section{DISCUSSION}

OVARIAN cancer is the fifth most common malignancy in women in the world ${ }^{(34)}$, yet little is understood about its etiology and less about its pathogenesis. Eighty-seven percent of ovarian cancers are epithelial in $\operatorname{origin}^{(34)}$.

The repeated growth and rupture of ovarian epithelium during follicular development and ovulation over the course of a female's reproductive lifetime creates a situation for growth factors to play a critical role in the cycle of continued epithelial proliferation and repair. These growth factors may also promote the growth of neoplastic epithelium. Activin, established as a growth and differentiation factor in a wide variety of tissues and present in abundance in ovarian granulosa cells and follicular fluid, it is a possible candidate for this action. ${ }^{(34)}$
In the current study, Activin A levels were found to be increased in the serum of subjects with epithelial serous cystadocarcinoma and mucinous ovarian carcinoma than benign cystadenoma and controls. Activin A secretion correlated significantly with tumor type $(\mathrm{P}<$ 0.05); mucinous tumors secreted significantly higher levels of activin A than serous tumors. Mucinous tumors secreted the highest level of activin A. Activin is thought to induce proliferation in epithelial ovarian carcinoma cell lines. ${ }^{(34)}$

Elevated serum activin A levels in subjects with epithelial ovarian carcinoma suggest that activin may be a factor contributing to tumorigenesis in these patients and that it might have a possible role in ovarian cancer ${ }^{(34)}$. Increased activin in ovarian tumors may represent an early event that leads to epithelial proliferation. ${ }^{(35,36)}$ Thus, Activin A may potentially serve as a 
tumor marker in the diagnosis and screening of serous and mucinous tumors.

Ovarian cancer cells proliferate in association with high levels of Activin A, which were correlated with advanced stages of the disease, especially with mucinous carcinoma. Activin A is thought not only to stimulate the proliferation of ovarian cancer cells but also has the selective advantage for allowing tumor cell survival because of the positive angiogenic and immunosuppressive effects that allow it to promote tumor growth. In addition, activin A enhances the invasive properties of ovarian cancer cells; most likely through up-regulation of cellular matrix metalloproteinases. Once tumorigenesis is initiated, however, activin signaling may enhance the metastatic process. ${ }^{(1)}$

In the present study, the serum levels of Follistatin increased significantly in patients with mucinous and serous ovarian carcinomas than cystadenoma and controls. This increase indicates that the Activin is not bound to its binding protein, follistatin. This keeps the activin free, thus increasing the effect of activin on induction of proliferation of ovarian cancer cells.

Follistatin (FS), an activin binding and neutralizing protein, was found to decrease proliferation in the cell lines producing activin ${ }^{(34)}$. In patients with advanced stage of tumors and hematological malignancies, free follistatin levels were elevated $^{(37)}$.

Activin signaling is regulated extracellularly by FS whereas a number of intracellular proteins act to modulate cellular responses to these activin signals. It is therefore the balance between activin and all of its modulators, rather than the actions of any one component, that determines the final biological outcome. ${ }^{(9)}$

Ovarian cancer cells receive a myriad of signals from molecules present in ascitic fluid or in the tumor microenvironment, and the interpretation of these signals ultimately results in the cellular response (e.g. grow, die, migrate,

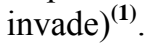

As regards Smad 2 mRNA it was found to be highly expressed in ovarian mucinous carcinoma (90\%) and in serous ovarian cystadenocarcinoma (75\%). This expression positively correlated with levels of activin A. These data provide a better understanding of the mechanism of action of the activin in the ovarian carcinoma. Similar results were detected in which Smad 2 mRNA levels were increased during $48 \mathrm{~h}$ treatment with activin A (50 ng $\mathrm{ml}(-1))$. $^{(38)}$

Activin A performs its signal transduction via Smads, which are pivotal intracellular nuclear effectors. Ligand-induced activation of activin A receptors with intrinsic serine/threonine kinase activity trigger phosphorylation of receptor-regulated Smads (R-Smads), whereas Smad2 and Smad3 are phosphorylated by TGF- $\beta$, and activin type I receptors, Smad1, Smad5 and Smad8, act downstream of BMP type I receptors. Activated R-Smads form heteromeric complexes with common-partner Smads (Co-Smads), e.g. Smad4, which translocate efficiently to the nucleus, where they regulate, in co- 
operation with other transcription factors, coactivators and corepressors, the transcription of target genes ${ }^{(39)}$.

It is shown that the Activin/Smad signaling pathway is functional in ovarian cancer cells which most probably causes positive angiogenic and immunosuppressive effects that allow it to promote tumor growth ${ }^{(40)}$. In addition, Activin $\mathrm{A}$ enhances the invasive properties of ovarian cancer cells; most likely through upregulation of cellular matrix metalloproteinases ${ }^{(41)}$, most probably through perturbation of the Smad pathway ${ }^{(41)}$.

The present study is among the few that evaluated the link between activin A and Smad pathway in ovarian cancer patients, rather than ovarian cell lines, since a significant positive correlation was found between Smad-2 mRNA and activin A. Perturbation of the Activin A/SMAD signaling pathway may result in progression of ovarian tumors through induction by Activin A. ${ }^{(11)}$ The results of the present study suggest that activin/Smad pathway may contribute to the aggressive behavior of ovarian cancer cells ${ }^{(35)}$. Several studies ${ }^{(11,35)}$ are in agreement with the present results. However, these studies were done on cell lines rather than patients.

Levels of uPA were elevated significantly in patients with serous and mucinous ovarian carcinoma than serous cystadenoma than controls, with highest levels in advanced stages of ovarian cancer.

In the present study, uPA concentrations were significantly higher in invasive tumors compared with low malignant potential tumors, which have been recognized as a separate entity, as the clinical course of these tumors is far more favorable when compared with their invasive counterparts. Similarly, uPA levels were higher in patients with metastases as compared with those without metastases.

These findings demonstrate that uPA is associated with the malignant progression of ovarian cancer. The results are consistent with the hypothesis that elevated levels of uPA may contribute to invasiveness and metastasis of ovarian cancer. These observations indicate a role of uPA in tumor progression and angiogenesis, and may be directly involved in cancer cell migration and invasion.

These results are in agreement with several other studies ${ }^{(42,}{ }^{43)}$. Hoffmann et al. ${ }^{(44)}$ were also able to demonstrate prognostic relevance of uPA for ovarian cancer. In contrast, van der Burg et al. ${ }^{(45)}$ who assessed uPA and PAI-1 among 90 patients ranging from stage $\mathrm{I}$ to stage IV disease, reported no correlation of UPA and PAI-1 with PFS or OS. The negative findings of that study possibly are attributable to the different laboratory assays, extraction procedures, and cut off values used. It should be mentioned, however, that Šprem et al. ${ }^{(46)}$ detected higher average concentrations of uPA in primary ovarian tumors, but due to large variations between tumors in a small number of patients, these higher values were statistically insignificant.

Proteolytic destruction of the basement membrane and tumor surrounding is a prerequisite of invasion and metastasis of tumor cells. In this process, uPA plays an 
important role because it is involved in the degradation of the components of the extracellular matrix and basement membrane ${ }^{(46)}$.

The serine protease uPA, in concert with its inhibitor PAI-1, promotes tumor cell adhesion, migration, and proliferation, as well as extracellular matrix degradation and, thus, facilitates tumor cell invasion and metastasis. ${ }^{(32)}$

Tumor cell invasion is dependent on finely regulated extracellular proteolytic activity, which allows tumor cells to invade the extracellular matrix. Among the proteolytic enzymes involved in this process are PAs, whose expression in cultured cells is regulated by several types of growth factors and cytokines ${ }^{(47)}$. Invasive tumor cells not only express cell-associated proteases but also secrete anti-proteases, preventing the overdigestion of the extracellular matrix, which leads to loss of cell attachment. The balance between proteolytic activity and inhibition is crucial in the invasive and metastatic event $^{(47)}$

A positive correlation was found between Activin A and levels of uPA. Thus, enhanced production of uPA was found most probably in response to elevated production of Activin A. Activin A induced the increase of net PA, which might result in strong proteolytic activity in some specific sites, such as areas of cell-to-cell or cell-to-extracellular matrix contacts. For this reason, drugs that manipulate or suppress signal transduction on the PA system in malignant cells offer a potentially new approach to anticancer therapy.
Plasma Bikunin levels were significantly decreased in serous and mucinous ovarian cancer than in cystadenoma and controls. Lowest levels were found in patients with metastasis.

Bikunin is a Kunitz-type protease inhibitor with tumor-suppressive potential in several malignant cell types, acting at the level of tumor invasion and metastasis ${ }^{(48)}$. It was subsequently demonstrated that bikunin inhibits tumor invasion, at least in part, by a direct inhibition of plasmin activity as well as by inhibiting $\mathrm{uPA}^{(49)}$. Mechanistic studies in several cell types demonstrated that bikunin interferes with an upstream target(s) of selected MAP kinase signaling processes such as phosphorylation of MEK and ERK, leading to overexpression of $\mathrm{uPA}^{(\mathbf{4 9})}$.

It has been reported that in preclinical studies with several types of malignant cells, bikunin is an antiinvasive and anti-metastatic agent ${ }^{(49)}$. In recently completed clinical studies, bikunin has been shown to stabilize disease progression in patients with advanced ovarian cancer ${ }^{(47)}$. Bikunin specifically inhibits expression of uPA mRNA and proteins, the molecular mechanism underlying the tumor-suppressive effect of bikunin remains elusive.

In the present study, bikunin inhibits uPA in ovarian cancer. This is in agreement with other studies, but on cell lines rather than on patients $^{(47,49)}$. From the present study, it can be hypothesized that low levels of Bikunin in ovarian cancer patients releases the inhibition of expression of uPA thus causing increase in uPA levels. Also, the low levels of bikunin 
in the ovarian cancer results in the stimulation of Activin A signaling as measured by the downstream signaling effector Smad2 expression. Furthermore, there was enhanced production of UPA in ovarian cancer cells in response to high levels of activin A secreted by these cancerous cells.

It can be suggested that bikunin may attenuate Activin A-elicited signaling cascades in ovarian cancerous cells and that probably provides the mechanism for the suppression of uPA expression. Thus, the up-regulation of the PA system in ovarian cancer cells is dependent upon activation of the Activin A-mediated ERK signal transduction cascade, which is downstream from an influx of extracellular calcium, and activation of tyrosine kinases and that bikunin can function as a non-voltagesensitive calcium channel blocker ${ }^{(47)}$.

The inverse correlation found between Bikunin and uPA as well as with Activin A is confirmed by the study by Hirashima $Y$ et al. ${ }^{(\mathbf{2 8})}$ in which expression of uPA and PAI-1 in the human ovarian cancer cell line HRA can be down-regulated by exogenous bikunin (bik), a Kunitztype protease inhibitor, via suppression of transforming growth factor-beta1 (TGF-beta1) upregulation and that overexpression of the bik gene can specifically suppress the in vivo growth and peritoneal dissemination of HRA cells in an animal model ${ }^{(28)}$. The results suggest that low bikunin in ovarian carcinoma may be associated with poor prognosis. It is conceivable that testing for bikunin may identify patients with ovarian carcinoma who are at high risk for early disease severity and a poor prognosis ${ }^{(27)}$. It is thought that plasma bikunin concentration is a strong and independent favorable prognostic marker for ovarian cancer ${ }^{(25)}$.

\section{Conclusions:}

Ovarian cancer has the highest mortality rate of the gynecological malignancies primarily because of the lack of early detection of the disease. The identification of novel signaling pathways involved in ovarian cancer progression is critical to the development of better diagnostics and more efficacious therapeutics.

In summary, the data provided here clearly demonstrate that circulating activin A levels were elevated in a serous and mucinous ovarian carcinoma. Thus, activin A induces the proliferation of both serous and mucinous ovarian carcinoma. Therefore, Activin A may be regarded as both a potential growth factor and a tumor marker is warranted.

The significantly elevated levels of serum follistatin (Activin - binding protein) in ovarian carcinoma indicated that activin is free and this modulated its signal transduction as illustrated by the expression of Smad2 in $90 \%$ of mucinous ovarian carcinoma and in $75 \%$ of serous cystadenocarcinoma. We show that the Activin/Smad signaling pathway is functional in ovarian cancer cells which most probably causes positive angiogenic and immunosuppressive effects that allow it to promote tumor growth. Also, evidenced by the present study, it is proposed that Smad-2 increased the levels of uPA which is a proteolytic enzyme that 
enhances tumor growth and progression as well tumor cell invasion and metastases.

Our data are the first to illustrate that low Bikunin levels were found to be associated with advanced ovarian cancer. It is postulated that Bikunin, a protease inhibitor, up regulated Activin (in the same manner that it up-regulated TGF-beta).These findings point to a novel role for bikunin in regulating the PA system and Activin A-mediated invasion. It is thought that plasma bikunin concentration might be a strong and independent favorable prognostic marker for ovarian cancer.

It can be concluded that bikunin might attenuate Activin A-elicited signaling cascades in ovarian cancer and that this probably provides the mechanism for the suppression of uPA expression. Treatment with bikunin may be beneficial as an adjuvant therapy to delay the appearance of metastatic disease and/or combined with cytotoxic agents to improve treatment efficacy in advanced ovarian cancers.

\section{REFERENCES}

1. Lesley D. Dunfield, Elizabeth J. Campbell Dwyer and Mark W. Nachtigal. TGFß-Induced Smad Signaling Remains Intact in Primary Human Ovarian Cancer Cells. Endocrinology 2002; 143, (4): 1174-1181.

2. Welt CK, Lambert-Messerlian G, Zheng W, Crowley WF Jr, Schneyer AL. Presence of activin, inhibin, and follistatin in epithelial ovarian carcinoma. J.
Clin. Endocrinol. Metab. 1997

Nov; 82(11):3720-7.

3. Luisi S, Calonaci G, Florio P, Lombardi I, De Felice C. Identification of Activin A and follistatin in human milk. Growh Factors. 2002; 20(3): 147-50.

4. Wankell M, Werner S. The role Activin in cytoprotection and tissue repair. Ann. NY. Acad. Sci. 2003; 995: 48-58.

5. Choi KC, Kang SK, Tai CJ, Auersperg N, Leung PC. The regulation of apoptosis by activin and transforming growth factorbeta in early neoplastic and tumorigenic ovarian surface epithelium. J. Clin. Endocrinol. Metab. 2001 May; 86(5):212535.

6. Tsuchida K, Vaughan JM, Wiater E, Gaddy-kurten D, Vale WW. Inactivation of activin-dependent transcription by kinase-deficient activin receptors. Endocrinology 1995; 136:5493-5503.

7. De Winter $\mathbf{J}$, Ten Dijke $\mathbf{P}$, de Vries CJM, van Achterberg TAE, Sugino H, De Waele P, Huylebroeck D, Verschueren K, Eijnden-van Raaij AJM. Follistatins neutralize activin bioactivity by inhibition of activin binding to its type II receptors. Mol Cell Endo 1996; 116:105-114.

8. Fukuda J, Ito I, Tanaka T, Leung PCK. Cell survival effect of activin against heat shock stress on OVCAR-3. Life Sci. 1998; 63:2209-2220.

9. Welt C, Sidis Y, Keutmann $\mathbf{H}$ and Schneyer A. Activins, Inhibins, and Follistatins: From 
Endocrinology to Signaling. A Paradigm for the New Millennium Experimental Biology and Medicine 2002; 227:724-752

10. Piek E, Heldin CH, Ten Dijke P. Specificity, diversity, and regulation in TGF-beta superfamily signaling. FASEB J. 1999 Dec; 13(15):2105-24.

11. Miyazono K. TGF-beta/SMAD signaling and its involvement in tumor progression. Biol Pharm Bull. 2000 Oct; 23(10):1125-30.

12. Chen $X$, Weisberg $E$, Fridmacher V, Watanabe $M$, Naco G, Whitman M. Smad4 and FAST-1 in the assembly of activin-responsive factor. Nature 1997; 389:85-89.

13. Pouponnot C, Jayaraman L, Massague J. Physical and functional interaction of SMADs and p300/CBP. J. Biol. Chem. 1998; 273:22865- 22868.

14. Wotton D, Lo RS, Swaby LA, Massague J. Multiple modes of repression by the Smad transcriptional corepressor TGIF. J. Biol. Chem. 1999; 274:3710537110.

15. Esch FS, Shimasaki S, Mercado M, Cooksey K, Ling N, Ying S, Ueno N, Guillemin R. Structural characterization of follistatin: a novel follicle-stimulating hormone release-inhibiting polypeptide from the gonad. Mol Endocrinol. $1987 \quad$ Nov; 1(11):849-55.

16. Patel K. Follistatin. Int. J. Biochem. Cell. Biol. 1998 Oct; 30(10):1087-93.

17. McConnell DS, Wang $Q$, Sluss PM, Bolf N, Khoury RH,
Schneyer AL, Midgley AR Jr, Reame NE, Crowley WF Jr, Padmanabhan V. A two-site chemiluminescent assay for activin-free follistatin reveals that most follistatin circulating in men and normal cycling women is in an activin-bound state. J. Clin. Endocrinol. Metab. 1998 Mar; 83(3):851-8.

18. Schneyer AL, Rzucidlo DA, Sluss PM, Crowley WF Jr. Characterization of unique binding kinetics of follistatin and activin or inhibin in serum. Endocrinology. 1994 Aug; 135(2):667-74.

19. Phillips DJ, McFarlane JR, Hearn MT, de Kretser DM. Inhibin, activin and follistatin bind preferentially to the transformed species of alpha 2macroglobulin.J. Endocrinol. 1997 Oct; 155(1):65-71.

20. Sugino $\mathbf{K}$, Kurosawa $\mathbf{N}$, Nakamura T, Takio $\mathbf{K}$, Shimasaki S, Ling N, Titani K, Sugino H. Molecular heterogeneity of follistatin, an activin-binding protein. Higher affinity of the carboxyl-terminal truncated forms for heparan sulfate proteoglycans on the ovarian granulosa cell. J. Biol. Chem. 1993 Jul 25; 268(21):15579-87.

21. Sugino H, Sugino K, Hashimoto O, Shoji H, Nakamura $T$. Follistatin and its role as an activin-binding protein. J Med Invest. 1997 Aug; 44(1-2):1-14.

22. Hughes RD, Evans LW. Activin $A$ and follistatin in acute liver failure. Eur J Gastroenterol. Hepatol. 2003; 15(2): 127-31. 
23. Fisher WH, Park M, Donaldson C, Vale W. Residues in the Cterminal region of Activin $\mathrm{A}$ determine specificity for follistatin and type II receptor binding. J Endocrinol 2003; 176(1): 61-8.

24. Yoshinaga K, Mimori $K$, Yamashita $\mathrm{K}$, Inoue $\mathrm{H}$, Mori M. Clinical significance of the expression of Activin $\mathrm{A}$ in esophageal carcinoma. Int $\mathrm{J}$ Oncol 2003; 22(1): 75-80.

25. Matsuzaki H, Kobayashi H, Yagyu T, Wakahara K, Kondo T, Kurita N, Sekino H, Inagaki K, Suzuki M, Kanayama N, Terao T. NEW: Plasma bikunin as a favorable prognostic factor in ovarian cancer. J. Clin. Oncol. 2005 Mar 1; 23(7):1463-72.

26. Kaczmarczyk A, Blom AM, Alston-Smith J, Sjoquist $\mathbf{M}$, Fries E. Plasma bikunin: half-life and tissue uptake. Mol. Cell. Biochem. 2005 Mar; 271(1-2):617.

27. Tanaka Y, Kobayashi H, Suzuki M, Kanayama N, Suzuki M, Yamakawa T, Morishita H, Terao T. Reduced bikunin gene expression as a factor of poor prognosis in ovarian carcinoma. Cancer. 2003 Jul 15; 98(2):424-30.

28. Hirashima $Y$, Kobayashi $H$, Suzuki M, Tanaka Y, Kanayama N, Terao $\mathbf{T}$. Transforming growth factor-beta1 produced by ovarian cancer cell line HRA stimulates attachment and invasion through an upregulation of plasminogen activator inhibitor type-1 in human peritoneal mesothelial cells. J. Biol. Chem. 2003 Jul 18; 278(29):26793-802.

29. Barkehall-Thomas A, Tong S, Baker LS, Edwards A, Wallace EM. Maternal serum activin A and the prediction of intrauterine growth restriction. Aust. N. Z. J. Obstet. Gynaecol. 2006 Apr; 46(2):97-101.

30. Lin SD, Kawakami T, Ushio A, Sato A, Sato S, Iwai M, Endo R, Takikawa Y, Suzuki K. Ratio of circulating follistatin and activin A reflects the severity of acute liver injury and prognosis in patients with acute liver failure. J. Gastroenterol. Hepatol. 2006 Feb; 21(2):374-80.

31. Suzuki M, Kobayashi H, Kageyama S, Shibata K, Fujie M, Terao T. Excretion of bikunin and its fragments in the urine of patients with renal stones. J. Urol. 2001 Jul; 166(1):268-74.

32. Schmitt M, Sturmheit AS, Welk A, Schnelldorfer C, Harbeck N. Procedures for the quantitative protein determination of urokinase and its inhibitor, PAI-1, in human breast cancer tissue extracts by ELISA. Methods Mol. Med. 2006; 120:245-65.

33. Carlos A. Muro-Cacho, Karen Rosario-Ortiz, Sandra Livingston and Teresita Muñoz-Antonia: Defective Transforming Growth Factor $\beta$ Signaling Pathway in Head and Neck Squamous Cell Carcinoma as Evidenced by the Lack of Expression of Activated Smad2. Clinical Cancer Research 2001; 7: 1618-1626. 
34. Welt CK, Lambert-Messerlian G, Zheng W, Crowley WF Jr, Schneyer AL. Presence of activin, inhibin, and follistatin in epithelial ovarian carcinoma. J Clin Endocrinol Metab. 1997 Nov; 82(11):3720-7.

35. Steller MD, Shaw TJ, Vanderhyden BC, Ethier JF. Inhibin resistance is associated with aggressive tumorigenicity of ovarian cancer cells. Mol. Cancer Res. 2005 Jan; 3(1):50-61.

36. Auersperg N, Wong AS, Choi KC, Kang SK, Leung PC. Ovarian surface epithelium: biology, endocrinology, and pathology. Endocr. Rev. 2001 Apr; 22(2):255-88.

37. Sakamoto Y, Shintani Y, Harada K, Abe M, Shitsukawa K, Saito S. Determination of free follistatin levels in sera of normal subjects and patients with various diseases. Eur J Endocrinol. 1996 Sep; 135(3):345-51.

38. Ito I, Minegishi T, Fukuda J, Shinozaki H, Auersperg N, Leung PC. Presence of activin signal transduction in normal ovarian cells and epithelial ovarian carcinoma. Br. J. Cancer. 2000 Apr; 82(8):1415-20.

39. Susumu Itoh, Fumiko Itoh, Marie-José Goumans and Peter ten Dijke. Signaling of transforming growth factor- $\beta$ family members through Smad proteins. European Journal of Biochemistry 2000; 267 (24): 6954.

40. Massague J, Blain SW, Lo RS. TGFB signaling in growth control, cancer, and heritable disorders. Cell 2000; 103:295309.

41. Rodriguez GC, Haisley C, Hurteau J, Moser TL, Whitaker R, Bast Jr RC, Stack MS. Regulation of invasion of epithelial ovarian cancer by transforming growth factor- $\beta$. Gynecol. Oncol. 2001; 80:245253.

42. Kuhn W., Schmalfeldt B., Reuning U., Pache L., Berger U., Ulm K., Harbeck N., Späthe K., Dettmar P., Höfler H., Jänicke F., Schmitt M., Graeff H. Prognostic significance of urokinase (uPA) and its inhibitor PAI-1 for survival in advanced ovarian carcinoma stage FIGO IIIc. Br. J. Cancer 1999; 79: 1746-1751.

43. Gottfried Konecny, Michael Untch, Astrid Pihan, Rainer Kimmig, Martina Gropp, Petra Stieber, Herrmann Hepp, Dennis Slamon and Mark Pegram. Association of Urokinase-Type Plasminogen Activator and Its Inhibitor with Disease Progression and Prognosis in Ovarian Cancer. Clinical Cancer Research 2001; 7: 1743-1749.

44. Hoffmann G., Pollow K., Weikel W., Strittmatter H. J., Bach J., Schaffrath M., Knapstein P., Melchert F., Pollow B. Urokinase and plasminogen activator-inhibitor (PAI-1) status in primary ovarian carcinomas and ovarian metastases compared to benign ovarian tumors as a function of histopathological parameters. 
Clin. Chem. Lab. Med.1999; 37: 47-54.

45. van der Burg M. E., HenzenLogmans S. C., Berns E. M., van Putten W. L., Klijn J. G., Foekens J. A. Expression of urokinase-type plasminogen activator (uPA) and its inhibitor PAI-1 in benign, borderline, malignant primary, and metastatic ovarian tumors. Int. J. Cancer 1996; 69: 475-479.

46. Marina Šprem, Damir Babiæ1, Marija Abramiæ, Ivan Vrhovec, Janez Škrk, Duško Milièiæ, Andreja Ambrioviæ Ristov, Dr'islav Kalafatiæ, Maja Osmak. Glutathione and Glutathione S-Transferases as Early Markers for Ovarian Carcinomas. CMJ Clinical Sciences 2001; 42(6):624-629.

47. Hiroshi Kobayashi, Mika Suzuki, Yoshiko Tanaka, Naohiro Kanayama, and Toshihiko Terao. A Kunitz-type Protease Inhibitor, Bikunin,
Inhibits Ovarian Cancer Cell Invasion by Blocking the Calcium-dependent Transforming Growth Factor- $\beta 1$ Signaling Cascade. J. Biol. Chem 2003; 278 (10): 7790-7799.

48. Kobayashi H., Suzuki M., Tanaka Y., Hirashima Y. and Terao T. Suppression of urokinase expression and invasiveness by urinary trypsin inhibitor is mediated through inhibition of protein kinase Cand MEK/ERK/c-Jun-dependent signaling pathways. J. Biol. Chem. 2001; 276: 2015-2022.

49. Kobayashi H., Suzuki M., Kanayama N., Nishida T., Takigawa M., and Terao $\mathbf{T}$. Suppression of urokinase receptor expression by bikunin is associated with inhibition of upstream targets of extracellular signal-regulated kinasedependent cascade. Eur. J. Biochem. 2002; 269: 39453957.

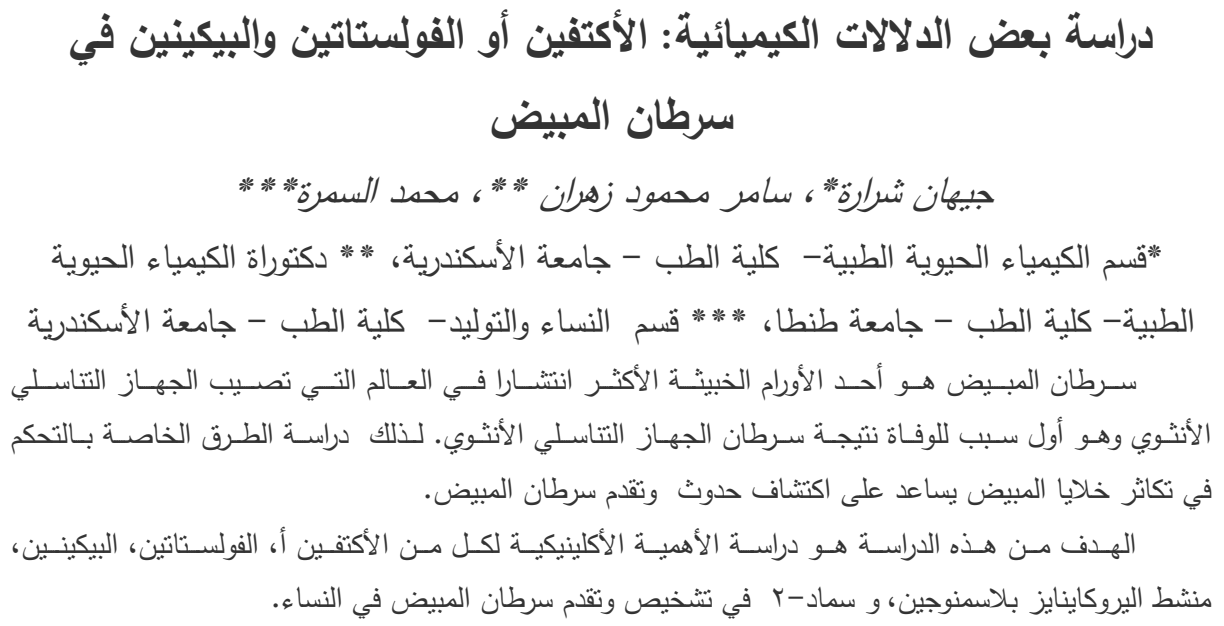




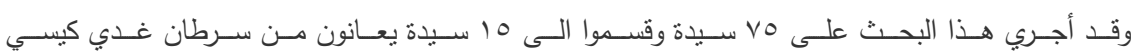

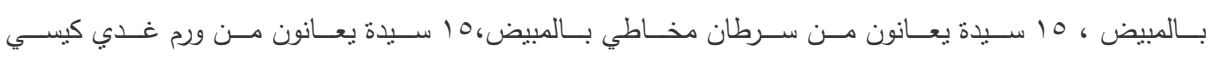
بالمبيض 10، سيدة خصبة و أصحاء و 10 أصحاء بعد سن انقطاع الحيض.

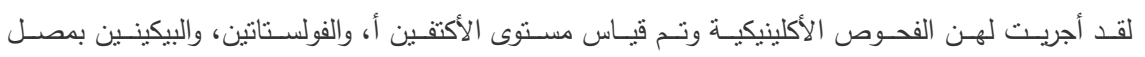

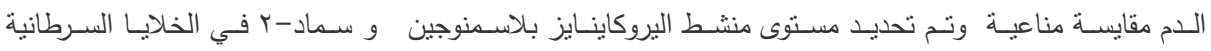
بالمبيض. وقـد تبـين أن نسـبة الأكتفِين أو الفولسـتاتين بمصـل الــم ارتفعـت فـي مرضـى سـرطان الغـدي الكبسـي

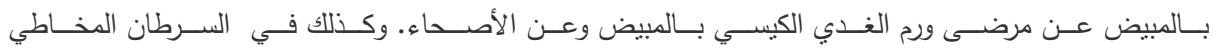

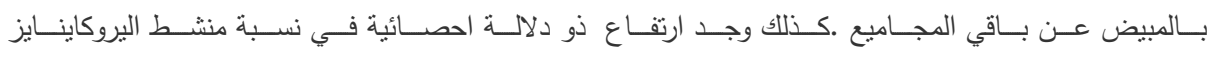

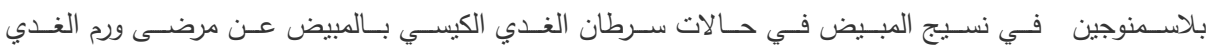

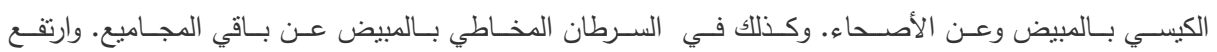
منشط اليروكاينايز بلاسمنوجين مع تقدم مراحل سرطان المبيض.

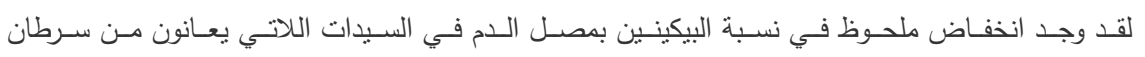

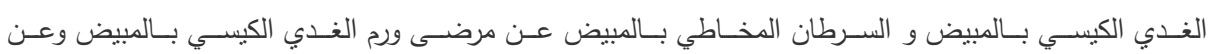
الأصحاء.

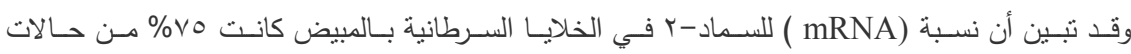

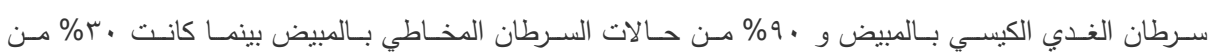

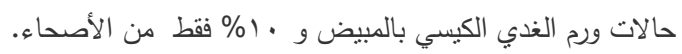

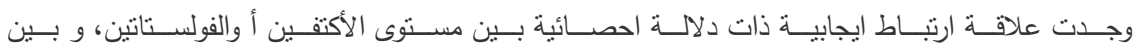

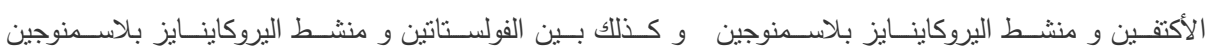

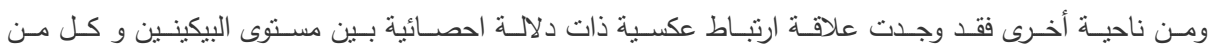

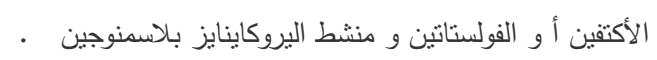

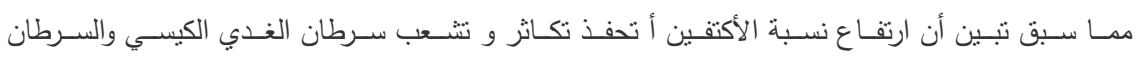

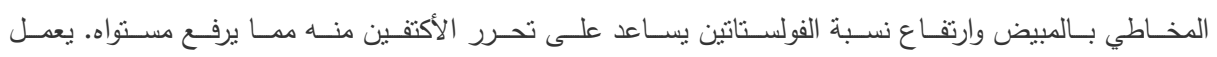

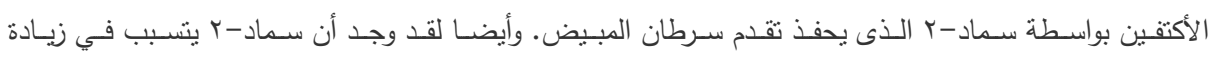

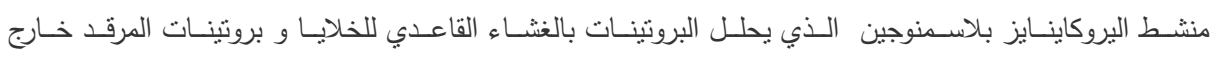

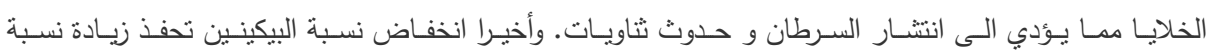

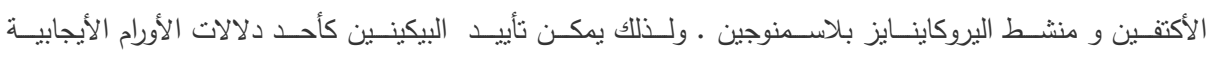

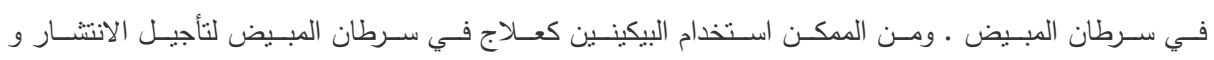
الثناويات. 